\title{
Reconhecimento, teoria crítica e sociedade: sobre desenvolvimento da obra de Axel Honneth e os desafios da sua aplicação no Brasil
}

CINARA L. ROSENFIELD" GIOUANI AGOSTINI SAAUEDRA*

\section{Resumo}

O artigo propõe traçar a evolução da Teoria do Reconhecimento através da obra de seu autor, Axel Honneth, e apresentar sua recepção no Brasil acompanhada de suas críticas e interpretações. Na primeira parte do artigo é apresentado o conjunto da obra do autor, buscando evidenciar sua evolução interna e os diálogos que Honneth estabelece com seus antecessores. Na segunda parte, discute-se a pertinência, abrangência ou adaptabilidade da Teoria do Reconhecimento a partir de dois pontos principais apontados pelas diversas interpretações da obra do autor: 1) a concepção individualista da autonomia e as suas implicações sobre o entendimento do papel da ação coletiva na luta pelo reconhecimento; 2) as dificuldades de operacionalização teórico-metodológica do seu sistema conceitual em estudos empíricos, e ainda associadas aos parâmetros cívicos europeus, ou mesmo alemães, sobre os quais o autor constrói sua noção de normatividade. Como será desenvolvido, esses temas se encontram articulados entre si e explorados pelos diferentes artigos que compõem o presente dossiê.

Palavras-chave: evolução da Teoria do Reconhecimento, crítica e interpretações, autonomia, estudos empíricos

\footnotetext{
पPós-Doutora em Sociologia. Doutorado em Sociologia do Trabalho pela Université Paris IX Dauphine. Professora do Programa de Pós-Graduação em Sociologia da Universidade Federal do Rio Grande do Sul (Brasil).E-mail: rosenfield@uol.com.br

${ }^{* *}$ Doutor em direito e em filosofia pela Universidade Johann Wolfgang Goethe. Professor do Programa de Pós-Graduação em Ciências Criminais da Faculdade de Direito da Pontifícia Universidade Católica do Rio Grande do Sul (Brasil).E-mail: giovani.saavedra@pucrs.br
} 


\section{Recognition, Critical Theory and Society: on the development of Axel Honneth's work and the challenges to its practical application in Brazil}

\section{Abstract}

The article aims to outline the development of the Theory of Recognition through the work of its author, Axel Honneth, and to present its reception in Brazil, as well as the criticism and interpretations of this theory. The first part of the article presents the author's body of work seeking to unveil its inner evolution and the dialogues established by Honneth with his predecessors. In the second part, we discuss the relevance, comprehensiveness or suitability of the Theory of Recognition from two main points highlighted by the various interpretations of the author's work: 1) the individualistic conception of autonomy and its implications on the understanding of the role of collective action in the struggle for recognition; 2) the difficulties regarding both theoretical and methodological operationalization of its conceptual framework within empirical studies, and its association to European, or even German, civic paradigms upon which the author builds his notion of normativity. The article concludes by showing how these themes are articulated and explored by the various works that comprise this dossier.

Keywords: Evolution of the Theory of Recognition. Criticism and interpreations. Autonomy. Empirical studies.

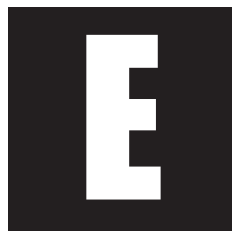

m seu livro, Crítica do Poder (Kritik der Macht), Honneth procurou salientar as características principais da tradição da Escola de Frankfurt, a fim de que a preocupação típica de uma Teoria Crítica da sociedade tivesse em evidência: "como o quadro categorial de uma análise, que, ao mesmo tempo, seja capaz de contemplar tanto as estruturas de dominação social como também os processos sociais de sua superação prática, deve ser elaborado?" (Honneth, 1988, p. 381-382)ํ․

\footnotetext{
${ }^{1}$ Todas as traduções de referências bibliográficas em língua estrangeira são traduções livres dos autores desse artigo.
} 
A estratégia de Honneth, nesta obra, foi a de dar uma resposta indireta ao problema, na medida em que ele apresenta a Teoria Crítica da Escola de Frankfurt como um processo de aprendizagem (Honneth, 1986a, p. 7-8; Honneth, 1988, p. 382). Porém, como esse procedimentose serve do método hegeliano de Descrição Histórica da Filosofia (Philosophiegeschichtsschreibung), Honneth precisou mostrar, de antemão, o critério a partir do qual o mesmo pode ser adequadamente realizado (Honneth, 1988, p. 382). Honneth encontrou esse critério na virada comunicativa da Teoria Crítica promovida por Habermas, porque o conceito habermasiano de interação apresentou-se para ele, desde o início, como uma saída teórica para as aporias da Teoria Crítica, nas quais ela desembocou por causa do seu conceito problemático de filosofia da história e do negativismo adorniano. Honneth usou as suposições fundamentais da teoria da ação de Habermas, a partir das quais a história da Teoria Crítica podia, então, ser compreendida como um processo de aprendizagem, como fio condutor da sua análise da Teoria Crítica desenvolvida em Kritik der Macht (Crítica do Poder) (Honneth, 1988, p. 382).

Habermas, porém, vincula o conceito de reconhecimento de tal forma à sua ética do discurso, que a simples participação livre na esfera pública parece ser suficiente para que as pessoas tenham preenchidas as suas expectativas de reconhecimento. Honneth entende que a expectativa de reconhecimento envolve uma série de elementos morais e éticos que não estão sendo levados em conta por Habermas (Honneth, 2004, p. 102).

Honneth procura, então, numa primeira fase do desenvolvimento de sua teoria, a partir da reconstrução das ideias de Mead e do jovem Hegel, delimitar o pano de fundo teórico sobre o qual ele pretende desenvolver a sua própria teoria crítica da sociedade. A interpretação que Honneth faz da teoria destes autores deixa claro que uma teoria da sociedade como aquela que ele pretende desenvolver deve partir do princípio 
de que as relações de reconhecimento contêm pretensões normativas na sua estrutura, as quais possibilitam o esclarecimento da mudança social. Ambos os autores identificaram uma ligação entre autorrelacionamento e reprodução da vida social, que está vinculada estruturalmente com as relações de reconhecimento. Por isso, a dinâmica do desenvolvimento histórico moral da sociedade deve ser entendida como uma luta por reconhecimento (Honneth, 1992, p. 148).

Porém, somente nos capítulos 5 e 6 do livro Luta por Reconhecimento (Kampf um Anerkennung) o leitor encontra, pela primeira vez, de forma explícita, uma explicação sistemática da teoria crítica da sociedade de Honneth. Nestes dois capítulos, o autor procura explicar como, no seu entendimento, surge e está constituída uma estrutura tripartite das relações de reconhecimento. Honneth, porém, não quer apresentá-la de forma puramente teórica e, portanto, procura conferir plausibilidade às suas afirmações teóricas comparando-as com os estudos empíricos e psicanalíticos de Donald W. Winnicott. Em um primeiro momento, Honneth pretende apresentar a dimensão das relações de reconhecimento do amor, que estão ancoradas estruturalmente na dimensão da natureza afetiva e dependente da personalidade humana.

Honneth encontra os primeiros elementos da sua teoria do reconhecimento na categoria da Dependência Absoluta de Winnicott. Esta categoria designa a primeira fase do desenvolvimento infantil, na qual tanto a mãe quanto o bebê se encontram de tal forma ligados, que surge uma espécie de relação simbiótica entre eles. A carência e a dependência total do bebê e o direcionamento completo da atenção da mãe para a satisfação das necessidades da criança fazem com que entre eles não haja nenhum tipo de limite de individualidade e ambos se sintam como unidade (Honneth, 1992, p. 160 ss.). Aos poucos, com o retorno gradativo aos afazeres da vida diária, este estado de simbiose vai se dissolvendo, a partir 
de um processo de ampliação da independência de ambos. Com a volta à normalidade da vida, a mãe não está mais em condições de satisfazer as necessidades da criança imediatamente.

A criança, então em média com seis meses de vida, precisa se acostumar com a ausência da mãe. Essa situação estimula na criança o desenvolvimento de capacidades que tornam o bebê capaz de se diferenciar do seu ambiente. Winnicott atribui a essa nova fase o nome de Relativa Independência. Nesta fase, a criança reconhece a mãe não mais como uma parte do seu mundo subjetivo e sim como um objeto com direitos próprios. A criança trabalha esta nova experiência por meio de dois mecanismos, que Honneth chama de Destruição e Fenômeno de Transição. O primeiro mecanismo é interpretado, pelo autor, a partir dos estudos de Jessica Benjamin, nos quais ela constata que os fenômenos de expressão agressiva da criança, nesta fase, acontecem na forma de uma espécie de luta, que ajuda a criança a reconhecer a mãe como um ser independente com reivindicações próprias. A mãe precisa, por outro lado, aprender a aceitar o processo de amadurecimento por que o bebê está passando. A partir dessa experiência de recíproco reconhecimento, os dois começam a vivenciar, também, uma experiência de amor recíproco, sem regredir a um estado simbiótico (Honneth, 1992, p. 164).

A criança, porém, só estará em condições de desenvolver o segundo mecanismo, se ela tiver desenvolvido, durante o primeiro, uma experiência elementar de confiança na dedicação da mãe. Então, com base nos estudos de Winnicott, Honneth esboça os princípios fundamentais do primeiro nível de reconhecimento. Quando a criança experimenta a confiança no cuidado paciencioso e duradouro da mãe, ela passa a estar em condições de desenvolver uma relação positiva consigo mesma. Honneth chama essa nova capacidade da criança de autoconfiança (Selbstvertrauen). De posse dessa capacidade, a criança está em condições de 
desenvolver, de forma sadia, a sua personalidade. Esse desenvolvimento primário da capacidade de autoconfiança é visto como a base das relações sociais entre adultos (Honneth, 1992, p. 168 ss.). Honneth vai além e sustenta que o nível do reconhecimento do amor é o núcleo fundamental de toda a moralidade (Honneth, 1992, p. 172 ss.). Portanto, este tipo de reconhecimento é responsável não só pela base de autorrespeito (Selbstachtung), mas também pela base de autonomia necessária para a participação na vida pública (Honneth, 2003, p. 174). Este primeiro e fundamental nível de reconhecimento é, portanto, conditio sine qua non do segundo nível do reconhecimento, a saber, o jurídico.

Nesta primeira fase de seu pensamento, a esfera do reconhecimento do amor é tratada como uma esfera ontológica, subtraída do processo de mudança histórica. Em seu livro, publicado em conjunto com Nancy Fraser, Redistribuição e Reconhecimento (Umverteilung und Anerkennung), e no posfácio da nova edição de seu livro Luta por Reconhecimento (Kampf um Anerkennung), Honneth corrigiu essa tese: hoje ele considera que também na esfera do amor pode ser encontrado um potencial normativo, que é desenvolvido historicamente através de conflitos e lutas sociais (Honneth, 2003c, p. 306-340; Honneth, 2003d, p. 129-224). Desde então, porém, não se sabe ao certo como Honneth pretende integrar os resultados da pesquisa de Winnicott em sua teoria. O desenvolvimento desse argumento mostrou que Honneth parece utilizar a teoria de Winnicott para esclarecer o desenvolvimento da autoconsciência (Selbstbewusstsein), assim como Hegel o fez na Enzyklopädie III (e não no capítulo correspondente da Fenomenologia do Espírito - Phänomenologie des Geistes)².

\footnotetext{
${ }^{2}$ Os limites deste artigo não permitem, porém, que esta tese seja aqui desenvolvida. Portanto, serão apenas citados os textos atuais de Honneth nos quais tal tese foi sustentada: Honneth, 2003e; Honneth, 2005, Honneth, 2007b e Honneth 2008b. Para a última versão da recepção Honnethiana da teoria de Hegel, mais especificamente de sua Filosofia do Direito, ver: Honneth, 2011.
} 
Duas perguntas guiam a análise de Honneth da segunda esfera do reconhecimento: (1) Qual é o tipo de autorrelação que caracteriza a forma de reconhecimento do direito? (2) Como é possível que uma pessoa desenvolva uma consciência de ser sujeito de direito? A estratégia utilizada por Honneth consiste em apresentar o surgimento do direito moderno de tal maneira, que, neste fenômeno histórico, também seja possível encontrar uma nova forma de reconhecimento. Neste ponto de sua argumentação, Honneth entende ser necessária uma diferenciação entre o modo como Mead determina as relações jurídicas e aquele desenvolvido por Hegel. De maneira muito curiosa, parece sustentar a hipótese de que a concepção jurídica de Mead corresponderia a uma visão tradicional de direito (pré-moderna) e aquela de Hegel seria uma espécie de concepção moderna de ordem jurídica (Honneth, 1992, p. 177).

Honneth procura mostrar que, junto com o surgimento de uma moral ou de uma sociedade pós-tradicional, houve também uma separação da função do direito daquela do juízo de valor (Wertschätzung). Na teoria de Ihrering e na tradição pós-kantiana de diferenciação de duas formas de respeito (Achtung), principalmente com base na pesquisa de Darwalls, encontra elementos para determinar a diferença entre direito e juízo de valor. Para o direito, a pergunta central é: como a propriedade constitutiva das pessoas de direito deve ser definida? No caso do juízo de valor: como se pode desenvolver um sistema de valor que esteja em condições de medir o valor das propriedades características de cada pessoa (Honneth, 1992, p. 183 ss.)?

Os sujeitos de direito precisam, portanto, estar em condições de desenvolver sua autonomia, a fim de que possam decidir racionalmente sobre questões morais. Aqui, Honneth tem em mente a tradição dos direitos fundamentais liberais e do direito subjetivo em condições pós-tradicionais, que indicam a direção do desenvolvimento histórico do direito (Honneth, 1992, p. 190 ss.). A luta por reconhecimento deveria, então, ser vista como 
uma pressão, sob a qual, permanentemente, novas condições para a participação na formação pública da vontade vêm à tona. Honneth esforça-se, naturalmente influenciado pelos escritos de Marshall, para mostrar que a história do direito moderno deve ser reconstruída como um processo direcionado à ampliação dos direitos fundamentais. Desse modo, ele pretende sustentar, portanto, que as três esferas dos direitos fundamentais que foram diferenciadas historicamente são o fundamento da forma de reconhecimento do direito, ou seja, reconhecer-se reciprocamente como pessoas jurídicas significa, hoje, muito mais do que no início do desenvolvimento do direito. Hoje, a forma de reconhecimento do direito contempla não só as capacidades abstratas de orientação moral, mas também as capacidades concretas necessárias para uma existência digna (Honneth, 1992, p. 190).

O direito deve ser visto, portanto, como a forma de expressão simbólica que, através da potencial efetivação da sua faculdade de entrar em juízo, permite ao ator social demonstrar que é reconhecido. Porém, mesmo assim, permanece sem resposta a pergunta sobre o tipo de autorrelação característico da forma de reconhecimento do direito. No caso do direito, este tipo específico de autorrelação é o autorrespeito (Selbstachtung) (Honneth, 1992, p. 194 ss.). No caso da forma de reconhecimento do direito, são postas em relevo as propriedades gerais do ser humano. No caso da valoração social, são postas em relevo as propriedades que tornam o indivíduo diferente dos demais, ou seja, as propriedades de sua singularidade.

Portanto, Honneth parte do princípio de que a terceira forma de reconhecimento, a saber, a Comunidade de Valores ou Solidariedade, deve ser considerada um tipo normativo, ao qual correspondem as diversas formas prática de autorrelação valorativa (Selbstschätzung). Honneth não aceita aquilo que Hegel e Mead consideram condição para este padrão de reconhecimento, pois ambos os autores estão convencidos da 
existência de um horizonte valorativo e intersubjetivo compartilhado por todos os membros da sociedade, como condição da existência da forma de relacionamento que Honneth chama de Solidariedade. Pelo contrário, ele procura mostrar que, com a transição da sociedade tradicional para a sociedade moderna, surge um tipo de individualização que não pode ser negado. A terceira esfera do reconhecimento deveria ser vista, então, como um meio social a partir do qual as propriedades diferenciais dos seres humanos venham à tona de forma genérica, vinculativa e intersubjetiva (Honneth, 1992, p. 197).

Nesta fase do desenvolvimento de sua teoria, Honneth denomina esta terceira esfera do reconhecimento de Solidariedade. Porém, em seu livro, publicado em conjunto com Nancy Fraser, Redistribuição e Reconhecimento (Umverteilung und Anerkennung), Honneth reinterpreta a esfera da solidariedade ou valoração social (Wertschätzung) a partir do princípio do Rendimento (Leistung) (Honneth, 2003c, p. 174 e ss.). Neste nível de integração social, encontram-se valores e objetivos que funcionam como um sistema de referência para a avaliação moral das propriedades pessoais dos seres humanos e cuja totalidade constitui a autocompreensão cultural de uma sociedade. A avaliação social de valores estaria, então, permanentemente determinada pelo sistema moral dado por esta autocompreensão social. Essa esfera de reconhecimento estaria, portanto, vinculada de tal forma em uma vida em comunidade que a capacidade e o desempenho dos integrantes da comunidade somente poderiam ser avaliados intersubjetivamente (Honneth, 1992, p. 197 ss.).

Para que os atores sociais possam, portanto, desenvolver um autorrelacionamento (Selbstbeziehung) positivo e saudável, eles precisam ter a chance simétrica de desenvolver a sua concepção de vida boa sem desenvolverem as patologias oriundas das experiências de desrespeito (Mißachtung). O que significa uma experiência de desrespeito permanece 
ainda sem resposta. Na verdade, porque à experiência do reconhecimento corresponde sempre uma forma positiva de experiência de si (Selbsterfahrung), Honneth precisa partir do princípio de que o conteúdo do que seja desrespeito deve estar implicitamente vinculado às reivindicações individuais por reconhecimento: se e quando o sujeito social faz uma experiência de reconhecimento, ele adquire um positivo entendimento sobre si mesmo; se e quando, ao contrário, um ator social experiencia uma situação de desrespeito, consequentemente, a sua positiva autorrelação, adquirida intersubjetivamente, adoece.

Para tornar a sua teoria plausível, Honneth precisa, por consequência, encontrar na história social traços de uma tipologia tripartite negativa da estrutura das relações de reconhecimento. Esta tipologia negativa deveria cumprir duas tarefas: (1) para cada esfera de relação de reconhecimento deve surgir um equivalente negativo, com o qual a experiência de desrespeito possa ser esclarecida, seguindo a estrutura da forma de reconhecimento correspondente; (2) a experiência de desrespeito deve ser ancorada de tal forma em aspectos afetivos do ser humano, que venha à tona a sua capacidade motivacional de desencadeamento de uma luta por reconhecimento.

À forma de reconhecimento do amor correspondem as formas de desrespeito definidas por Honneth como maus tratos (Mißhandlung) e violação (Vergewaltigung). Nesta forma de desrespeito, o componente da personalidade que é atacado é aquele da integridade psíquica, ou seja, não é diretamente a integridade física que é violentada, mas sim o autorrespeito (selbstverständliche Respektierung) que cada pessoa possui de seu corpo, que, como já foi visto, é adquirido por meio do processo intersubjetivo de socialização originado através da dedicação afetiva (Winnicott) (Honneth, 1992, p. 214 ss.). Exatamente por causa deste complexo desenvolvimento psicossocial do autorrespeito, ele e a sua forma correspondente de reconhecimento não podem ser esclarecidos historicamente. 
À forma de reconhecimento do direito corresponde a forma de desrespeito intitulada privação de direitos (Entrechtung) e, nesta esfera do reconhecimento, o componente da personalidade que é ameaçado é aquele da integridade social. Também aqui, Honneth precisa encontrar a forma correspondente de desrespeito lá onde um tipo específico de autorrelação pode se encontrado, a saber, o autorrespeito. Central para a análise feita por Honneth das formas de desrespeito é o fato de que todo o tipo de privação violenta da autonomia deve ser vista como vinculada a uma espécie de sentimento. Pelo menos nesta fase do desenvolvimento de sua teoria, o sentimento de injustiça ocupa um papel importante na análise que faz do direito (Honneth, 1992, 216). Porém, apesar de Honneth ressaltar, em um primeiro momento, o papel do sentimento de injustiça, logo em seguida a sua análise passa a considerar um tipo de respeito cognitivo da capacidade de responsabilidade moral que um ator social vivencia numa situação de desrespeito jurídico. Portanto, o conteúdo do que significa ser imputável moralmente em cada situação depende do grau de universalização e também do grau de materialização do direito (Honneth, 2003, p.216).

À forma de reconhecimento da solidariedade corresponde a forma de desrespeito da degradação moral (Entwürdigung) e da injúria (Beleidigung). Honneth entende que a dimensão da personalidade ameaçada é aquela da dignidade (Würde). Também aqui, a experiência de desrespeito deve ser encontrada na degradação de uma forma de autorrelação que, no caso, é aquela da autoestima (Selbstschätzung). A pessoa aqui é privada da possibilidade de desenvolver uma estima positiva de si mesma (Honneth, 1992, p. 217). Ao contrário da esfera do reconhecimento do amor, tanto esta esfera quanto aquela do direito dependem de uma estrutura social que muda e evolui historicamente. 
Como Honneth sempre tem em mente uma específica forma de autorrelação e de identidade, estruturalmente vinculada a uma pessoa humana, e como o conteúdo normativo da sua teoria é sempre desenvolvido ex negativo, ou seja, deve ser deduzido da destruição da respectiva forma de autorrelacionamento ou reconhecimento, fica claro que há sempre, como pano de fundo de sua análise, uma concepção antropofilosófica não explícita que, de alguma forma, está permanentemente presente quando Honneth tenta definir a estrutura das relações de reconhecimento ${ }^{3}$. Parece claro, ademais, que, quando Honneth esclarece a forma de desrespeito correspondente à forma de reconhecimento do amor, delineia-se também de maneira indireta uma espécie de núcleo antropo-ontológico da estrutura das relações de reconhecimento.

Em seu livro Reificação (Verdinglichung), Honneth parece ter encontrado um caminho para integrar a teoria de Winnicott em sua teoria do reconhecimento de modo a explicitar esse núcleo antropo-ontológico de sua concepção de reconhecimento. Neste livro, Honneth introduz uma nova dimensão em sua teoria: a dimensão existencial do reconhecimento e utiliza a teoria de Winnicott para descrever alguns de seus aspectos. Desde a introdução dessa nova dimensão, Honneth tem se confrontado com uma série de problemas teóricos, para os quais ele ainda não apresentou uma resposta suficiente. O principal deles é: como esta dimensão existencial do reconhecimento se relaciona com a dimensão sócio-histórica da sua teoria?

A forma como Honneth pretende desenvolver essas intuições, porém, não é clara. Em dois textos, no seu artigo Invisibilidade (Unsichtbarkeit) ${ }^{4}$ e no seu livro Reificação (Verdinglichung) ${ }^{5}$, ele parece tentar dar-

\footnotetext{
${ }^{3}$ Essa parece ser também a interpretação de Heidegren (2002) e sua interpretação foi explicitamente recepcionada por Honneth no seu Nachwort (em:Honneth, 2003c: 307 ss.). Sobre o assunto compare também: (Honneth/Joas, 1980).

${ }^{4}$ Honneth, 2003e.

${ }^{5}$ Honneth, 2005.
} 
Ihes uma forma sistemática. $\mathrm{O}$ autor não se manifesta, porém, claramente a esse respeito. Qualquer análise que pretenda, portanto, esclarecer conexões entre esses textos já envolve uma interpretação ativa. Pretendese, dessa forma, no que segue, defender a tese de que Honneth procura, nesses trabalhos, desenvolver a sua antropologia do reconhecimento.

Em ambos os escritos, Honneth está interessado em esclarecer o que acontece no ato do reconhecimento, através da oposição entre conhecimento (Erkennen) e reconhecimento (Anerkennen) (Honneth, 2003 e, p. 8-9). Ao contrário da tese desenvolvida no texto Invisibilidade, porém, ele reinterpreta esses dois verbos como duas formas existenciais do Ser-Humano (zwei existentielle Modi des Menschseins): o Modo do Conhecer (der Modus des Erkennens) e o Modo do Reconhecer (der Modus des Anerkennens). A sua tese é que o Modo do Reconhecer precede o Modo do Conhecer.

Essa primazia do Modo do Reconhecer caracteriza o que Honneth passa a chamar de Modo Existencial do Reconhecimento (Der existentielle Modus der Anerkennung). Neste livro, o autor deixa claro que pretende diferenciar duas diferentes dimensões da sua teoria. Ele entende que esse Modo Existencial do Reconhecimento deve ser compreendido como uma forma mais fundamental do Reconhecimento (dimensão antropológica do reconhecimento) que serve de base para as esferas do reconhecimento (dimensão socio-histórica do reconhecimento) (Honneth, 2005, p. 60 , nota de rodapé 19). Porém, diferentemente do que à primeira vista poderia parecer óbvio, o fenômeno da reificação não consiste em uma primazia do Modo do Conhecer em relação ao Modo do Reconhecer. Reificação consiste, para Honneth, numa forma de Esquecimento-do-Reconhecimento (Anerkennungsvergessenheit) (Honneth, 2005, p. 71).

Em geral, podem-se identificar três dimensões do fenômeno da reificação: as dimensões da Autorrelação (Selbstbeziehung), da Intersubjetivi- 
dade (Intersubjektivität) e da Relação-com-o-Mundo-Objetivo (Beziehung zur objektiven Welt). Na dimensão da intersubjetividade, sempre há uma primazia do reconhecimento. Na relação do indivíduo com o mundo objetivo, esta primazia nem sempre está presente, já que o mundo objetivo pode ser apreendido, ainda que o indivíduo o compreenda como um objeto (Honneth, 2005, p. 78). Esse não parece ser o caso das relações intersubjetivas, porque nós perdemos a capacidade de reconhecer um outro ser humano "assim que o reconhecimento caiu em esquecimento" (sobald uns ihre vorgängige Anerkennung in Vergessenheit geraten ist) (Honneth, 2005, p. 78). Em ambos os casos, a utilização do conceito de reificação deve ser, portanto, assimétrica (Honneth, 2005, p. 78).

Honneth salienta que, na análise de Lukács do fenômeno da reificação, já podia ser encontrada uma terceira dimensão deste fenômeno. Ao lado da reificação das relações intersubjetivas e das relações com o mundo objetivo, Lukács cita também a possibilidade da reificação das relações dos indivíduos consigo mesmos. Neste caso, o mundo dos atos mentais é apreendido como um espaço fenomênico, no qual, ao invés de desenvolver uma sadia simpatia (Anteilnahme) positiva consigo mesmo, o indivíduo compreende a si mesmo como um objeto a ser analisado do ponto de vista do observador (Honneth, 2005, p. 80). Lukács salientou a possibilidade de que um fenômeno como este possa acontecer, mas não a desenvolveu teoricamente. Honneth procura, portanto, preencher este vazio na teoria da reificação de Lukács. Ele descreve o fenômeno da autorreificação como um dos casos de Esquecimento-do-Reconhecimento. Pode-se observar um fenômeno desse tipo, portanto, quando a autoafirmação (Selbstbejahung) cai em esquecimento (Honneth, 2005, p. 93).

Uma das dificuldades do livro Reificação é exatamente compreender de que forma essa dimensão existencial do reconhecimento se relaciona com a dimensão socio-histórica do reconhecimento. Além disso, 
não fica claro, na exposição do autor, de que maneira a capacidade para a autoafirmação (Selbstbejahung) e para a autorreificação (Selbstverdinglichung) estão relacionadas com o reconhecimento ou dependem do reconhecimento do indivíduo pelo Outro (das Andere) ${ }^{6}$. O fato de Honneth utilizar, no livro Reificação, a teoria de Winnicott para esclarecer uma série de elementos principais do conceito de reconhecimento na dimensão da autorrelação (Selbstbeziehung) (Honneth, 2005, p. 81) mostra claramente, porém, que ele encontrou uma forma de resolver esses problemas através de uma releitura da argumentação sobre a esfera do reconhecimento do amor, tal como ele a desenvolveu no livro Luta por Reconhecimento (Honneth, 1992, p. 157 e ss.).

Em recente texto, Do Desejo ao Reconhecimento (Von der Begierde zur Anerkennung) (Honneth, 2008b), ele confirma essa intuição. Trata-se, aqui, de uma interpretação do capítulo sobre a Autoconsciência (Selbstbewusstsein) da Fenomenologia do Espírito (Phänomenologie des Geites) de Hegel. Honneth pretende, a partir da análise deste artigo, esclarecer a função dessa nova dimensão da sua teoria. A escolha deste capítulo já é, neste caso, um indício neste sentido. Hegel considera, neste período, antropologia como parte da fenomenologia (Hösle, 1998, 351 e ss.) ${ }^{7}$. Já o título que Hösle escolhe para o capítulo de seu livro sobre o sistema hegeliano, em que ele trata da antropologia de Hegel na Fenomenologia do Espírito (Phänomenologie des Geites), parece trazer à tona os motivos que levaram Honneth a se dedicar a um estudo desta parte da obra hegeliana. Hösle deu a esse capítulo o nome: "A Antropologia: da natureza à liberdade" (Die Anthropologie: Von der Natur zur Freiheit) (Hösle, 1998, 351

\footnotetext{
${ }^{6}$ Neste ponto, Honneth cita apenas o livro de Ernst Tugendhats: Egozentrizität und Mystik (Honneth, 2005, p. 89, nota de rodapé 18).

${ }^{7}$ Somente em sua Enzyklopädie, Hegel dedicará um capítulo especial à antropologia: Hegel, 1830/1986, cap. A.
} 
e ss.). Honneth, talvez, tivesse intitulado esse texto da seguinte forma: A Antropologia: da primeira à segunda natureza. De fato, parece claro que nesse novo texto, Honneth integra elementos tanto da sua interpretação de McDowell quanto de Winnicott. Em outras palavras, ele parece ter encontrado, no capítulo da Autoconsciência, da Fenomenologia do Espírito, de Hegel, a metodologia adequada para integrar motivos de ambos os autores na sua teoria do reconhecimento.

Como de costume, a análise hegeliana da Autoconsciência (Selbstbewusstsein) é composta de três estágios com duas passagens (Übergänge). O desafio é sempre o mesmo: para que se compreenda adequadamente a tese que Hegel está desenvolvendo, é necessário, em primeiro lugar, que se compreenda como esses três estágios são constituídos e os motivos que justificam a passagem de um estágio para o outro. Por outro lado, só é possível chegar a uma definição adequada desses três estágios, caso se esteja em condições de identificar o motivo que guia a estruturação sistemática dos mesmos. Cada estágio precisa, então, em um segundo momento, ser interpretado como uma concretização deste motivo. Para Honneth, Hegel pretende, com ajuda de seu método fenomenológico, provar que um sujeito só desenvolve uma consciência (Bewusstsein) de seu selbst, quando é capaz de se envolver em uma relação de reconhecimento (Honneth, 2008b, p.16).

O objetivo hegeliano, neste artigo, é do tipo transcendental: Hegel quer esclarecer o fato transcendental que demonstra a raiz de toda a sociabilidade humana (Honneth, 2008b, p.2). Além disso, ele pretende mostrar como se dá a passagem do ser natural para o ser intelectual (vom natürlichen zum geistigen Wesen) (Honneth, 2008b, p. 16). Essa passagem é, por fim, interpretada por Hegel como um movimento que vai da Autorrelação (Selbstbezüglichkeit) do puro desejo ou instinto para uma 
renovada consciência de dependência relacional do ser humano (Honneth, 2008b, p. 16).

No primeiro estágio de sua análise fenomenológica da Autoconsciência, Hegel descreve um tipo de Consciência que possui atividades mentais, porém ainda não está em condições de compreendê-las como uma diferença, isto é, neste estágio da análise fenomenológica, não é possível que uma noção de Autoconsciência venha à tona. Para que o sujeito se torne consciente dessa diferença, ele precisa aprender a apreender a sua atividade corporal. Ele precisa, portanto, primeiro aprender, a partir da relação consigo mesmo, a apreender a realidade de tal forma, que a realidade passe a lhe aparecer como uma realidade intencional, cujo objetivo é a satisfação de necessidades elementares (Honneth, 2008b, p. 21). O sujeito aprende que ele não pode apreender a realidade apenas do ponto de vista epistemológico, mas também como um ser vivo que se reproduz naturalmente (Honneth, 2008b, p. 23). O sujeito faz, dessa forma, nessa primeira passagem, uma experiência transcendental: ele experiencia retrospectivamente que ele só pode desenvolver as condições necessárias para a apreensão do conceito de vida, porque ele desenvolveu uma relação prática e ativa com o objeto (Honneth, 2008b, p. 23). Os paralelos da descrição desse primeiro estágio epistemológico com a interpretação de Honneth da teoria de McDowell são óbvios: tanto aqui quanto lá, Honneth pretende desenvolver uma terminologia filosófica que lhe permita superar os dualismos da tradição transcendental da filosofia (Honneth, 2008 b, p. 26). Assim, ele mostra, em um segundo momento, que também Hegel compreende essa passagem como um continuum entre primeira e segunda natureza. Depois dessa passagem, o sujeito desenvolve uma consciência da sua dupla natureza (Honneth, 2008b, p. 23).

A passagem do segundo estágio para o terceiro estágio é interpretada por Honneth a partir da teoria de Winnicott. No início deste 
segundo estágio, o sujeito compreende a totalidade da realidade como um produto da sua capacidade mental e age de acordo. Somente a experiência de que a realidade possui exigências próprias, isto é, de que ela é independente da sua capacidade mental, leva o sujeito a compreender a si mesmo como um ser autoconsciente (Honneth, 2008b, p. 31). Hegel pretende, portanto, descrever aqui um processo similar ao que Winnicott descreve em seus estudos: assim como a criança, na análise de Winnicott, teve que apreender a perceber a mãe como um sujeito "com exigências pessoais independentes da criança", também o sujeito hegeliano precisa compreender que a realidade à sua frente, diferentemente de um objeto, tem exigências pessoais, é um ser humano. Somente essa experiência vai levar o sujeito a se compreender como um ser humano autoconsciente diferente dos outros. Com essa passagem, o sujeito aprende a apreender os outros sujeitos como sujeitos com intencionalidade, ou seja, que não agem necessariamente conforme a vontade do sujeito (Honneth, 2008b, p. 31). Com esse passo, está completamente realizada a passagem fenomenológica para a dimensão do reconhecimento. Reconhecimento e Autoconsciência estão, portanto, diretamente vinculados. O fenômeno da coisificação nada mais é do que uma falha nesse processo de aprendizagem.

Como vimos, portanto, seu aporte à compreensão da dimensão social dos processos identitários e de construção da autonomia individual repousa sobre três esferas do reconhecimento: dedicação emotiva, respeito e estima social. Para os indivíduos poderem dispor de suas autonomias individuais, é preciso que socialmente sejam reconhecidas suas necessidades, sua igualdade legal e/ou suas contribuições sociais. O que reverte na possibilidade de o sujeito realizar sua autonomia individual ao desenvolver uma autorrelação marcada, respectivamente, pela autoconfiança, autorrespeito e autoestima. A definição de reconhecimento 
remete a três esferas: a do amor, a do Direito e a da solidariedade/contribuição/performance (Leistung no original, e utilizado de forma variada conforme diferentes tradutores e compreensões dos textos do autor em diversos momentos). É a experiência de falta de reconhecimento em uma ou mais dessas esferas - violação, privação e exclusão, respectivamente -, que serviria de motivação para a luta por reconhecimento ${ }^{8}$.

A interação entre os sujeitos passível de reconhecimento social traz consigo, de maneira articulada, um processo de individualização, na medida em que aumentam as chances de expressão, legitimação e reconhecimento de diferentes facetas da personalidade do sujeito, e um processo de inclusão social ao inserir o sujeito em uma comunidade de valores e em um círculo igualitário composto de todos os membros da sociedade.

O progresso nas condições de reconhecimento social surge nas duas dimensões de individualização e inclusão social: ou novas partes da personalidade são abertas ao reconhecimento mútuo, então surge a extensão da individualidade social confirmada; ou mais pessoas são incluídas nas relações existentes de reconhecimento, de forma que o círculo de sujeitos que reconhecem uns aos outros cresce (Honneth, 2003b, p. 186).

Possibilitar o desenvolvimento individual e a autorrealização dos sujeitos constitui o verdadeiro objetivo (ou demanda) de um tratamento igualitário entre os sujeitos nas nossas sociedades, e só possível pela experiência do reconhecimento intersubjetivo da autonomia individual, das necessidades específicas e das capacidades particulares. Ao explorar a noção de inclusão social através da intersubjetividade, a Teoria do Reconhecimento permite alçar os processos identitários a uma dimensão

\footnotetext{
${ }^{8}$ Agradecemos à doutoranda do PPG Sociologia da UFRGS Andressa Corrêa pela leitura atenta desta parte do artigo em sua primeira versão e pelas importantes contribuições feitas ao seu aprimoramento.
} 
social, convertendo as questões da autonomia individual em questões de natureza social. Segundo o autor, a experiência de injustiça dá-se quando aspectos da personalidade - que se acredita possuírem direito ao reconhecimento - são desrespeitados. A igualdade entre os sujeitos é perpassada pela formação identitária pessoal que é dependente das relações de reconhecimento mútuo, num círculo contínuo entre individual e social.

A abordagem do reconhecimento, tal qual desenvolvida por Honneth, atrela-se a dois temas explorados pelo autor: as patologias sociais e os paradoxos do capitalismo.

O tema das patologias do social remete à noção de uma sociedade "normal", como sendo aquela que garante aos seus membros a realização de si (individual), que asseguraria aos sujeitos uma "boa vida" ou vida bem sucedida, definida segundo um julgamento normativo. As patologias sociais são deficiências sociais que resultam em atentados às condições sociais de autorrealização individual.

Já os paradoxos do capitalismo remetem à tese de que o "novo" capitalismo conseguiu mobilizar novos recursos motivacionais, a partir da herança do Estado Social do pós-guerra e do modelo taylorista e fordista de trabalho. Essas heranças significaram um notável progresso moral para a humanidade, em termos de atributos desejáveis ou obrigatórios das relações entre os sujeitos. No entanto, essas aquisições institucionalizadas (normas e valores) são instrumentalizadas pelo capitalismo flexível, no sentido de que este tem sucesso em "guardá-las", ao mesmo tempo em que logra erodir seu caráter emancipador. São as seguintes as aquisições institucionalizadas: a) o individualismo como representação dominante de si; b) a ideia de igualdade universal como forma de regulação jurídica; c) a ideia de performance (Leistung) como princípio de atribuição de status ou de posição social; d) a ideia de amor romântico como avanço emocional dos elementos institucionalizados da vida cotidiana (Cf. Honne- 
th, 2006, p.277). O paradoxo, emblemático do capitalismo atual, dá-se na combinação das esferas do progresso moral com a sujeição que engendra o seu contrário (Honneth, 2006): 1) o individualismo, entendido como autonomia e autenticidade, reverte-se em implicação pessoal não somente como fonte de realização de si e enobrecimento humano, mas como norma a ser seguida, o que significa tornar-se refém da lógica instrumental; 2) a extensão de direitos e formas de participação, entendida como maior autonomia individual, reverte em maior responsabilização de si e enfraquecimento das responsabilidades sociais, inclusive do Estado, de maneira a se tornarem de gerência e responsabilidade única dos sujeitos; 3) a noção de performance como contribuição, como capacidade de participar de maneira igualitária na construção do todo social, reverte em uma simbiose da base objetiva e de base subjetiva das relações, embaralhando duas fronteiras. O chamado paradoxo do capitalismo reside no fato de essa contradição não ser percebida como atrelada ao capitalismo, pois os sujeitos "tornaramse" responsáveis por seus destinos e empresários de si mesmos e, assim, aparentemente autônomos em relação às imposições do sistema.

O conjunto da Teoria do Reconhecimento é atravessado de maneira obrigatória pelas questões relativas à justiça social. Segundo Honneth, não há justiça sem reconhecimento; dito diferentemente, o que os indivíduos esperam da vida em sociedade é a possibilidade de terem reconhecidas as suas capacidades, potencialidades e contribuições ao todo social pelos "outros generalizados".

A noção de reconhecimento teria a contribuição de articular, com vistas à justiça social, as esferas das relações privadas, dos direitos, da performance. Segundo Honneth, mudam as formas históricas de reconhecimento e suas esferas, mas a necessidade de reconhecimento é universal, essencial e, portanto, inerente à integração social. Os princípios de reco- 
nhecimento permitem, na sociedade moderna ocidental, refletir sobre o conteúdo da noção de justiça.

Sem a experiência de que o outro indivíduo seja um próximo/semelhante, nós não estaríamos em condições de dotálo com valores morais que controlam ou restringem o nosso agir; portanto, primeiramente precisa ser consumado esse reconhecimento elementar, precisamos tomar parte (Anteilnehmen) do outro existencialmente, antes de podermos aprender a orientar-nos por normas do reconhecimento que nos intimam a determinadas formas de consideração ou de benevolência (Honneth, 2008, p.73).

Honneth afirma o valor universal da justiça e do bem-estar. A luta por justiça só pode se concretizar a partir de uma base comum de valores. Sem critérios normativos, a crítica não é possível. Daí a teia de valores éticos que serve de substrato para as experiências de injustiça. É preciso partir de uma certa essência antropológica mínima, para se pensar a justiça "essencial", sendo o reconhecimento uma dimensão fundamental da justiça, intrínseca às necessidades dos sujeitos. O autor trabalha sempre em três níveis: a dimensão antropológica ("mínima" e essencial), a dimensão sociológica e a dimensão evolutiva-histórica (há uma noção de bem-comum normativo a perseguir, de maneira a distinguir o que é bom daquilo que é mau). Partindo destas dimensões, à noção de justiça é preciso articular o conteúdo empírico próprio a cada sociedade concreta e particular. O eixo estruturador da sua obra, a relação entre reconhecimento e justiça social, será mais explorado a seguir através das críticas e contribuições dadas pelos seus intérpretes, com ênfase àqueles que integram este dossiê. 


\section{Críticas, contrapontos e interpretações}

No Brasil e internacionalmente, veem-se desenvolver discussões acerca da pertinência, abrangência ou adaptabilidade da Teoria do Reconhecimento, que giram em torno de dois pontos principais: 1) a concepção individualista da autonomia e suas implicações sobre o entendimento do papel da ação coletiva na luta pelo reconhecimento; 2) as dificuldades de operacionalização teórico-metodológica do seu sistema conceitual em estudos empíricos, associadas, ainda, aos parâmetros cívicos europeus, ou mesmo alemães, sobre os quais o autor constrói sua noção de normatividade. Como se desenvolverá a seguir, esses temas encontram-se articulados entre si e são explorados pelos diferentes artigos que compõem o presente dossiê.

O primeiro tema decorre da interpretação de que a Teoria do Reconhecimento estaria calcada em uma noção de justiça social que priorizaria a autorrealização individual construída pelas relações intersubjetivas de reconhecimento. Essa assertiva, embora correta, não pode ser entendida em seu sentido estrito, sob pena de, efetivamente, a justiça social ser compreendida em termos puramente individuais. A esta crítica de uma concepção individualista da autonomia pessoal, Honneth, em conjunto com Anderson, em seu texto Autonomia, Vulnerabilidade, Reconhecimento e Justiça (Anderson, Honneth, 2011) contrapõe uma teoria da autonomia baseada no reconhecimento. Neste texto, os autores afirmam que a busca de felicidade e autorrealização pessoal, quando entendida como liberdade e autonomia em relação aos demais parceiros sociais, só se sustentaria para aqueles que não necessitam de suportes sociais. Os autores, ao contrário, clamam pela justiça social alinhada com uma concepção de autonomia relacional, social, intersubjetiva, situacional, baseada no reconhecimento. De maneira que autonomia seria a capacidade que existe somente em um contexto social de 
relações que a sustentam e somente em conjunção com sentido interno de ser autônomo (Nedelsky apud Anderson, Honneth, 2011, p. 85).

No nosso entendimento, uma grande contribuição da Teoria do Reconhecimento é sua capacidade de articular a dimensão individual e a dimensão social. O reconhecimento é o elo entre as duas dimensões incontornáveis da vida em sociedade: a autorrealização pessoal e as relações intersubjetivas, de um lado, a rede de suporte social e de sociabilidade capaz de servir de substrato para a autonomia e a liberdade, de outro. Não estamos longe da concepção de Durkheim de individualismo moral, o indivíduo é sempre social, e o todo sempre é maior que a soma das partes.

Ao recusarem a abordagem das teorias liberais sobre as condições de realização de autonomia, defendem que a frustração pelos desrespeitos e pela ausência de reconhecimento, além de desencadear lutas por reconhecimento, impede a realização de autonomia, condição para uma vida em liberdade em um ambiente de justiça social.

Em uma tradição que retorna a Hegel e a George Hebert Mead, esses três modos de "autorrelação prática" podem ser vistos como aqueles que são adquiridos e mantidos somente quando se é reconhecido por aqueles que também se reconhece. Autoconfiança, autorrespeito e autoestima não são, portanto, meramente crenças sobre si mesmo ou estados emocionais, mas propriedades que emergem de um processo dinâmico no qual indivíduos passam a experienciar a si mesmos como possuidores um certo status, seja como um objeto de preocupação, como um agente responsável, como um contribuinte valorizado de projetos compartilhados ou como o que quer que seja. A autorrelação de alguém não é, então, uma questão de um ego solitário refletindo sobre si mesmo, mas o resultado de um processo intersubjetivo contínuo, no qual sua atitude frente a si mesmo emerge em seu encontro com a atitude do outro frente a ele. (Anderson, Honneth, 2011, p.88) 
Honneth expõe, ainda, de maneira clara, o papel do grupo na constituição das identidades individuais, no texto traduzido de forma inédita neste dossiê ${ }^{9}$ : O eu no nós; Reconhecimento como força motriz de grupos. O autor realiza uma reflexão sobre o conceito de grupo, procurando demonstrar o caráter parcial seja da concepção psicanalítica - que, de maneira caricatural, nega o papel positivo que o grupo pode ter sobre o desenvolvimento individual pelo fato do "eu" poder ser anulado pelo efeito de grupo -, seja da concepção sociológica e da ciência política - que não identifica a ameaça representada pelo grupo sobre o desenvolvimento individual, ao enaltecer a ideia de grupo como uma comunidade cultural, de valores e tradições comuns que contribui à construção de uma identidade individual. Recorre ao conceito de reconhecimento como aquele capaz de demonstrar que, através de um conjunto infinito de relações intersubjetivas, a construção do sujeito dá-se pelo processo de socialização. O pertencimento a um grupo social favorece a construção constante dos três elementos constitutivos de uma relação positiva para consigo mesmo: a autoconfiança, o autorrespeito e a autoestima, sendo esta última a que mais floresce no seio dos grupos sociais, haja vista a exigência da aprovação pelo olhar constante dos outros, à medida que os círculos de socialização se complexificam.

Assim, o papel positivo dos grupos repousa sobre a partilha de valores, que é fundamental à constituição do sujeito. É possível haver uma patologização de grupos sociais, sendo que a socialização patológica é a responsável pelo desvirtuamento dos grupos sociais. Honneth explora dois tipos de patologizações: o primeiro deles estaria ligado ao acúmulo, em dado grupo, de um tipo de personalidade que permaneceu estacionado no estágio das idealizações primitivas, por não ter concluído os processos

\footnotetext{
${ }^{9}$ Costaríamos de agradecer à Editora Surkampf por liberar o direito autoral do texto, em especial a Dra. Petra Hardt, assim como a Nadia Lucia Fuhrmann pela intermediação junto à editora. Igualmente, manifestamos nosso agradecimento à doutoranda do PPG Sociologia/UFRGS, Mathilde Mondon-Navazo, por nos ter ofertado um resumo do texto em francês para sua divulgação.
} 
de separação [da sua progenitura]. Uma segunda forma de patologização estaria ligada ao acúmulo de um tipo de personalidade que tem um potencial quase incontrolável de agressividade devido a experiências anteriores de desrespeito ou abandono. Conclui,

Através da via indireta da demonstração dos desvios negativos eu queria fundamentar uma vez mais a tese que estava no centro de minha exposição: o eu busca o nós da vida comum em grupo porque mesmo depois de amadurecido ele ainda depende de formas de reconhecimento social que possuam o denso caráter da motivação direta e da confirmação. Ele não pode manter nem o autorrespeito nem a autoestima sem a experiência de apoio que ele faz através da prática de valores compartilhados no grupo. Por conseguinte, o grupo, longe de representar uma ameaça para a identidade pessoal, é, nas palavras de Adorno, uma "fonte da humanidade". (Honneth, p. 77 deste dossiê)

O texto contribui à reflexão do tema da luta por reconhecimento e sua vinculação necessária a movimentos coletivos proposta por alguns intérpretes da Teoria do Reconhecimento. A fim de aportar ao debate acerca do caminho necessário aos movimentos sociais para atingir uma efetiva luta por reconhecimento sem reduzir o papel do coletivo nesta luta, é possível uma interpretação, com auxílio do texto em questão, de que não é propriamente necessário um movimento social para conformar uma luta por reconhecimento, sem, no entanto, prescindir do papel do grupo na busca por reconhecimento. Neste sentido, o texto "O eu no nós" pode servir de inspiração para a compreensão da luta no seio de um grupo e não necessariamente em um movimento social formalmente delimitado. Uma tal interpretação permitiria refletir acerca da luta não mais em um sentido literal e formal, mas como busca com e junto a "outros". A construção da identidade individual necessita do social seja para se consolidar, seja para se expressar sob a forma de busca. O coletivo mantém seu papel normativo na busca por reconhecimento entre aqueles que 
vivenciaram o desrespeito social, mas as formas de luta coletiva podem ser múltiplas, aí incluídos os movimentos sociais.

Mattias Iser (Departamento de Ciências Sociais da Johann Wolfgang Goethe-Universität Frankfurt/Main), no texto que integra este dossiê, intitulado Desrespeito e Revolta, vai ainda mais longe, ao demonstrar a ênfase excessiva dada - eventualmente pelo próprio Honneth inclusive - à questão identitária em seu sentido mais psicológico, e propor sua superação pelo entendimento ampliado da noção de reconhecimento ,através do que Iser denomina de conceito de reconhecimento deontológico. É conhecido o comprometimento da Teoria Crítica com a perspectiva de mudança e decorre daí a atribuição central que deveria haver na Teoria do Reconhecimento, segundo Iser, ao papel da revolta e ao progresso dela decorrente. Se um bem sucedido autorrelacionamento individual oportunizado pelas condições concretas de uma vida em sociedade é um objetivo teoricamente inovador, a sua acentuação demasiada na interpretação da teoria honnethiana pode enfraquecer a potencialidade do conceito de revolta e seu substrato calcado na injustiça moral, por estar por demais focada na autorrealização individual. Iser, ao mesmo tempo em que se opõe a esta tese "psicologizante" e individualista, mostra como o correto entendimento da Teoria do Reconhecimento remete a uma concepção coletiva através da noção de revolta.

Iser argumenta que as expectativas de reconhecimento devem ser compreendidas em seus aspectos psicológicos e normativos. Aquele que se revolta não só foi atingido pessoalmente, mas também por ter tido recusado algo ao qual acredita ter legitimamente pretensão. A demanda por reconhecimento encontra-se na esfera da Razão, por exigir a referência a normas capazes de identificar o direito a pretender. O conceito deontológico de reconhecimento proposto pelo autor supõe a centralidade dos deveres recíprocos. Necessidades basais-corpóreas e interativas (nos ter- 
mos do autor), ou seja, "materiais", podem se transformar em normativas quando são fundamentadas perante os outros.

Quando um sujeito registra, por exemplo, que reagiu com revolta ao não-respeitar de suas necessidades ou de suas características e não com indiferença ou puro desgosto, então, abre-se para ele a perspectiva de que ele acredita ter uma exigência, que precisa ser fundamentada perante os outros. Somente quando o sujeito pode introduzir razões do porquê suas necessidades basais-corporais ou interativas devem ou até mesmo precisam ser satisfeitas pelos outros, trata-se de expectativas normativas (ainda que essas possam ser injustificadas). Frequentemente, fundamenta-se a revolta no fato de que o sujeito acredita ter tido desrespeitado seu status normativo; o status, que a ele pertence em função de um determinado valor dentro de um relacionamento específico. Nesse sentido, podem o desgosto e o ódio se transformar em revolta, quando se compreende (se acredita compreender), que se dispõe de uma exigência justificada, que foi violada. (Iser, p. 97 deste dossiê)

Assim, ao vincular o conceito de reconhecimento ao sentimento de revolta, as diferentes dimensões do reconhecimento remetem aos deveres de reconhecimento recíproco e não à vulnerabilidade psíquica. As três esferas de reconhecimento de Honneth, ou os "três níveis de análise: o nível forma de autorrelação, a ser protegida, dos direitos e deveres implícitos, assim como valores fundidos", segundo Iser, são objetivos de autoproteção individual que justificam a existência da moral. Essa perspectiva estreita ainda mais a relação entre moral e justiça, pois o bem-estar da sociedade não é medido por condições de reconhecimento recíproco que garantam a identidade pessoal e autorrealização individual, mas sim que garantam a proteção moral dos sujeitos. As expectativas normativas e as necessidades psíquicas inserem-se em um processo de "retroalimentação", conforme o autor. E mais, Iser introduz a noção de pretensões de status (ao invés de pretensões de identidade, como em Honneth), entendidas como, 
O conceito de "status" faz referência mais forte, pelo contrário, a práticas compartilhadas, nas quais pessoas se encontram umas com as outras em determinadas relações normativas. Nesse contexto, quer se dizer com status, primeiramente, aquela descrição também desigual de determinados direitos ou deveres, de acordo com os quais nós somos reconhecidos em uma determinada ordem, por exemplo, também teocrática. O respectivo status é definido através de expectativas morais intersubjetivas, que seguramente são influenciadas por identidades, porém, não são por elas fixadas. A frustração dessas expectativas pode conduzir à resistência. Da mesma forma, essas expectativas valem, no mínimo, nos respectivos contextos, como fundamentadas, porém, podem ser também colocadas em dúvida. Somente o conceito de status do reconhecimento deontológico indica, de um lado, aquele conteúdo normativo, que uma teoria crítica necessita, e torna possível, de outro lado, a criação de uma ponte para aqueles motivos, que podem conduzir a uma luta por reconhecimento. (Iser, pp. 112-113 neste dossiê)

Concluindo, os destaques de cunho individual e psicológico dados às pretensões identitárias como télos do reconhecimento recíproco impediriam, inclusive, de se conceber a injustiça contra outros sujeitos, já que eu próprio não estaria atingido. Se a experiência psíquica de desrespeito é, sem dúvida, um meio concreto de descobrir injustiças - e, portanto, é e deve ser objeto de crítica social -, não é o único modo, já que podemos, por vários motivos, ter baixas expectativas ou aceitar falsamente outras tantas. É possível reconhecer injustiças que não nos atingem pessoalmente ao estender a amplitude da noção de reconhecimento a um status normativo que traz consigo os sentimentos de revolta e de humilhação. Iser conclui que somente o sentimento de revolta é capaz de servir de chave, para abrir a nós uma análise adequada de todas as experiências de desrespeito social (Iser, p. 118 neste dossiê).

No texto da Rahel Jaeggi (Instituto de Filosofia da Humboldt-Universität zu Berlin), apresentado neste dossiê e intitulado Reconhecimento 
e subjugação; sobre a relação entre teorias positivas e negativas da intersubjetividade, a autora retoma o tema da luta por reconhecimento sob novo ângulo, ao problematizar o caráter positivo imanente aos processos de reconhecimento, uma vez que estes podem também constituir-se em relações de dominação e subjugação. As relações de reconhecimento podem ser formas de reificação e de identificação "congelante". Trata-se de facetas negativas da intersubjetividade, que vêm de par com sua faceta positiva de dependência do reconhecimento do outro na construção da identidade. Assim, as teorias positivas de intersubjetividade (Fichte, Hegel, Habermas, Taylor e Honneth) compreendem que as relações de reconhecimento recíproco são condições de possibilidade de sua liberdade e de suas possibilidades de ação (Jaeggi, p. 125 neste dossiê). Já nas teorias negativas da intersubjetividade (Sartre, Althusser, Butler), o olhar do outro pode destituir a liberdade ao se constituir o reconhecimento, finalizando por reificar e objetivar, sem que seu objeto se identifique com o rótulo que lhe é imposto. Nesse sentido, a autora critica as teorias negativas da intersubjetividade, defendendo que a luta é pelo reconhecimento "adequado", e demonstrando que tais teorias: 1) fazem um retorno a um romantismo residual da subjetividade autêntica, uma subjetividade, portanto, que localiza sua autenticidade na esfera (fictícia) de um espaço de autorreferência desimpedida, livre das exigências e cunhações dos outros (Jaeggi, p. 134 neste dossiê); 2) estão presas a um conceito negativo de liberdade, da "liberdade como indeterminação", alegando que "sem determinação não se é livre mas indeterminado" (Jaeggi, p. 136 neste dossiê); 3) entendem o reconhecimento como uma relação ontológica precedente, ao passo que o reconhecimento intersubjetivo é algo que se realiza numa relação prática (e até em disputas práticas e por vezes conflituosas), se constitui praticamente (Jaeggi, p. 137 neste dossiê). Daí a defesa da noção de luta por reconhecimento, de maneira que as teorias positivas 
da intersubjetividade não significam que os sujeitos estão previamente de acordo em uma dada relação, mas que o reconhecimento ocorre no acontecimento real de disputa e de conflito. Conclui sua crítica às teorias negativas sem deixar, no entanto, de alertar às teorias positivas de que façam jus à luta por reconhecimento sem exacerbá-las tragicamente ou entendê-las mal agonisticamente (Jaeggi, p. 138 neste dossiê). A luta por reconhecimento toma contornos específicos, pelo entendimento, proposto pela autora, de que a positividade da Teoria do Reconhecimento não significa necessariamente um olhar sempre ideologizante ou reificador, e sim como uma arena possível de luta que não está, no entanto, já isenta de patologias (falsos reconhecimentos) e paradoxos (falsas autonomias).

Emil Sobottka (PPG Ciências Sociais PUCRS), em seu artigo intitulado Liberdade, reconhecimento e emancipação; raízes da teoria da justiça de Axel Honneth, e também presente neste dossiê, busca, através da análise do recente livro publicado por Honneth, $O$ direito da liberdade: esboço de uma eticidade democrática, lançado em junho de 2011 e ainda sem tradução no Brasil, apresentar uma mudança de direção na análise do autor ao explorar o potencial emancipatório das próprias instituições, como alternativa à luta por reconhecimento calcada em relações intersubjetivas diretas. Sobottka traça um histórico da evolução da Teoria Crítica no interior da Escola de Frankfurt, tendo como eixo de análise as noções de liberdade e emancipação inseridas em uma teoria da Justiça. Inicia com as bases da teoria, passando por Kant, Hegel e Marx, expõe dois dos expoentes da Escola de Frankfurt - Horkheimer e Habermas -, e culmina com a exposição do livro de Axel Honneth em questão, no qual o autor explora a noção de liberdade como o critério ético nas diferentes esferas da vida.

Não sem razão a forte ênfase que Honneth colocou no que se poderia designar de desenvolvimento do sujeito individual autônomo a partir de microrrelações intersubjetivas foi criticada como restritiva, tornando insuficiente sua proposta 
teórica para dar conta adequadamente da complexidade das atuais sociedades. Reconhecida a dificuldade de fazer valer produtivamente as conclusões sobre reconhecimento para uma análise das instituições sociais centrais das sociedades modernas, Honneth se engaja numa releitura da Filosofia do direito de Hegel em busca de uma base filosófica mais sólida para seu projeto. Um primeiro resultado dessa empreitada é o opúsculo Sofrimento de indeterminação (Honneth, 2007). Com essa releitura de Hegel, Honneth preparou o caminho para um projeto bem ambicioso: desenvolver uma teoria da justiça. Não surpreende que ele o faça em estreita vinculação ao que foi também, em sua visão, o projeto de seu mestre: desenvolver essa teoria na forma de uma análise social. O direito da liberdade [...] é o livro que resultou desse projeto. (Sobottka, p. 158 neste dossiê)

Segundo Sobottka, se em a Luta por Reconhecimento (2003a) a capacidade de autonomia do sujeito, e, portanto, a sua própria liberdade, baseava-se em suas relações intersubjetivas diretas, no livro em questão, Honneth dirige sua análise às instituições sociais e seu potencial emancipatório. Não restritamente aos princípios normativos que as orientam e à consequente acomodação às suas normas, mas através de um procedimento metodológico por ele denominado de "reconstrução normativa", no qual se insere a avaliação crítica do potencial emancipatório das próprias instituições. A partir da releitura da Filosofia do Direito de Hegel, Honneth identifica três conotações distintas que a liberdade, historicamente, assumiu: a liberdade negativa (ausência de forças coercitivas à livre vontade dos sujeitos), a liberdade reflexiva (julgamento moral das normas, constituindo-se de espaço de "refúgio" individual), a liberdade social (esta sim dependente do reconhecimento recíproco e dependente da intersubjetividade entendida como constitutiva do indivíduo em sociedade).

O texto crítico de Pinzani (2012), a respeito da mesma obra de Honneth, mas com uma interpretação alternativa, acrescenta outras traduções para dois destes três tipos de liberdade: a liberdade negativa ou jurídica, 
a liberdade moral e a liberdade social. Tais liberdades seriam progressivas e positivas, tal qual as três esferas de reconhecimento, mas adaptadas ao texto em questão: relações íntimas, mercado e Estado democrático. Interessante notar que o tema da liberdade individual e o valor superior que Ihe é atribuído pelas sociedades ocidentais propicia o projeto de identificar, nestas esferas, como e quanto realizam a liberdade individual, de maneira a igualmente identificar aquilo que determinada sociedade considera justo. É possível encontrar nesta proposta uma ponte com a difícil tarefa de dar conteúdo empírico à teoria da Justiça, e do Reconhecimento, por conseguinte, o que nos permite introduzir o segundo ponto de discussão, a saber, as dificuldades de operacionalização da teoria para a pesquisa empírica. Ao buscar dar conteúdo empírico à noção de justiça, colocam-se, igualmente, as dificuldades, apontadas por alguns autores, decorrentes da sua concepção teórica estar alicerçada sobre a realidade europeia.

Nadia Lucia Fuhrmann (Pós-Doutorado PPG Sociologia UFRGS), em artigo neste dossiê intitulado O Primado do Reconhecimento sobre a Redistribuição: a origem dos conflitos sociais a partir da teoria de Axel Honneth, propõe-se a superar esta dificuldade, analisando o fenômeno de "rualização" infanto-juvenil no meio urbano à luz da Teoria do Reconhecimento. Sua pesquisa empírica realiza-se em duas instituições assistenciais de Porto Alegre, que oferecem o Serviço de Apoio Socioeducativo (SASE). O objetivo da pesquisa foi investigar as origens desse fenômeno e as múltiplas formas de violência a que crianças e adolescentes estão expostos na cidade de Porto Alegre. A autora analisou as estratégias político-sociais que se propõem a minimizar, ou até mesmo erradicar o fenômeno da rualização.

A reflexão a partir da Teoria do Reconhecimento mostra que a principal origem dos conflitos vividos pelas crianças e jovens atendidos pelo SASE diz respeito à ausência de reconhecimento social em várias 
esferas da vida desses indivíduos, especialmente, na esfera familiar. Mais do que razões essencialmente econômicas, é a falta de reconhecimento social que está no cerne das conflitualidades urbanas vividas por essas crianças e jovens. Desenvolve a hipótese de que o não reconhecimento é a principal causa da violência urbana envolvendo crianças e jovens e busca demonstrar que políticas públicas de distribuição de renda desarticuladas das práticas assistenciais e educativas não contribuem para a redução das conflitualidades urbanas. Conclui, portanto, que os eventos de violência, conflitos e riscos envolvendo crianças e adolescentes têm sua origem no âmbito familiar e se agravam quando não há apoio comunitário e políticas públicas adequadas. O Programa SASE, política pública que foi explorada empiricamente e caracteriza-se por ser um espaço de proteção, de socialização, desenvolvimento pessoal, social e cognitivo, no turno inverso ao da escola curricular. Está voltado ao atendimento de crianças e jovens das classes populares, atingidos pela desestruturação familiar, o abandono afetivo, moral, intelectual e o desprezo social, e contribui para o fortalecimento das três dimensões do reconhecimento: o amor, o direito e a estima social, de maneira a propiciar a reintegração social desta população ao mantê-la longe das ruas, assim como o suporte social e pedagógico adequado. A autora nos fornece, assim, um exemplo bem-sucedido da operacionalização de uma teoria cujos níveis de abstração e complexidade filosófica poderiam inibir sua utilização para análise da realidade empírica.

Há também trabalhos empíricos que colocam em discussão se o fato de a Teoria do Reconhecimento ter sido construída em relação a uma norma europeia ocidental, e mais ainda alemã, impossibilita sua utilização como teoria de base para análises empíricas alhures. Em geral, se poderia afirmar que a tarefa de repensar suas categorias para outras realidades, como a do Brasil, ainda está inconclusa, em que pesem iniciativas em sentido contrário como o do artigo supracitado. Nesse sentido, 
poderíamos citar o trabalho de Corrêa (2012), que procura exatamente colocar em discussão esse problema. Ela demonstrou, em seu estudo sobre Empreendimentos de Economia Solidária, casos de humilhação e desrespeito que não foram vividos como tal pelos atores, o que impede, segundo a autora, a luta por reconhecimento. Seu argumento, baseado em autores como Jessé de Souza (2006) e Cardoso de Oliveira (2004), seria o de que, por diferentes motivos apontados respectivamente por estes autores, relativos a questões vinculadas ao desenvolvimento do capitalismo, aos processos de constituição de direitos, a questões históricas e culturais, a sociedade brasileira não estaria plenamente inserida em uma lógica cívica. Assim, a tese honnethiana de que situações de humilhações seriam substrato para lutas por reconhecimento não teria se verificado empiricamente, o que tornaria a realidade brasileira não passível de importação de categorias de reconhecimento forjadas na realidade alemã:

Devido ao contexto aludido, o referencial honnethiano se enfraquece, pois a premissa igualitária mínima, a qual permite que os sujeitos percebam as injustiças e considerem-se dignos de demandar junto à sociedade, inexistiria na sociedade brasileira como referência única do corpo social. Condição que não permite, de um lado, que sujeitos valorizem os que não se inserem nos padrões de estima colocados por eles e, de outro, que indivíduos, principalmente os que ocupam posições desqualificadas, construam uma imagem positiva de sua contribuição social. Dupla indicação que inibe as lutas por reconhecimento, por limites externos e internos aos sujeitos, impedindo a possibilidade apontada por Honneth da efetivação de processos que contribuam para o progresso moral, o qual ocorreria a partir da discussão pública dos potenciais normativos inscritos nas diferentes esferas do reconhecimento. (Corrêa, 2012, pp. 46-47)

A reflexão da autora permite, pois, problematizar a recepção da Teoria do Reconhecimento e sua aplicação no Brasil, no sentido de que a tarefa universalizante dessa teoria estaria sendo colocada em xeque pela 
pesquisa empírica e que seria difícil se pensar e operacionalizar a Teoria do Reconhecimento para analisar sociedades existentes por todo o globo: como fazê-lo se a concepção que estrutura sua noção de justiça não pode ser automaticamente "importada" para a realidade concreta de todas as sociedades, embora simultaneamente se imponha preservar seu núcleo essencialista e normativo do que é justo?

Pinzani (2012) segue caminho crítico complementar, discorrendo sobre o livro $O$ direito da liberdade: esboço de uma eticidade democrática. Segundo o autor, Honneth afirmaria, no referido livro, que o principal trabalho deveria ser feito pelo trabalho conceitual e não pela pesquisa empírica. A tarefa desta seria indicar empiricamente os efeitos patológicos e renovar a institucionalização da moral. Dito diferentemente, a pesquisa empírica deveria mostrar o que é patológico, entendido como uma ofensa às estruturas normativas. Assim, poderia ser capaz de mostrar como operar com um estreito conceito de liberdade conduz a patologias do tipo que impedem a participação completa na vida social. A liberdade não poderia ser entendida nem em um sentido unicamente legal, nem somente romântico de autorrealização. Qualquer um destes sentidos, tomado separadamente, nos conduziria a patologias sociais.

O caráter macrossocial e filosófico da reflexão de Honneth implicam, de fato, um desafio para a pesquisa empírica, que tem a complexa tarefa de encontrar mediações adequadas entre concepções teóricas e análise da realidade empírica, tarefa esta realizada com considerável dificuldade pelos seus intérpretes brasileiros, seja pela já aludida ausência de mediações de mais baixa abstração do que aquelas exploradas em seus textos teóricos, como pela construção da reflexão com base na realidade europeia, e mais especificamente ainda na realidade alemã. Ao propor dar conteúdo empírico para a estruturação histórica e localizada da noção de justiça nas diferentes sociedades, abre-se uma possibilidade de operacionalização de uma teoria de alta abstração. Todavia, permanece a dificuldade de arti- 
culação entre teoria e empiria, na medida em que a tarefa do empírico seria dar conteúdo histórico aos sentidos de justiça e de boa-vida em cada sociedade, preservando a normatividade essencial do que é justiça. Como esta contribuição de conteúdo empírico poderia colaborar a ultrapassar uma suposta noção essencialista da justiça? A normatividade necessitaria se tornar permeável ao aporte empírico. O conteúdo do que é justo deveria pressionar a noção normativa e mais essencialista do que é justo.

Pinzani reforça a crítica do esvaziamento de conteúdo empírico presente nas reflexões de Honneth, mesmo no texto em questão, no qual este último busca transpor tal hiato entre teoria e empiria:

Além disso, chamam a atenção os fatos de Honneth não tratar o mercado financeiro, hoje tão dramaticamente importante, e não mencionar em momento nenhum a grande cisão histórica marcada pela queda do Muro e pelo fim do socialismo real - o que admira, em uma obra que pretende oferecer uma reconstrução normativa baseada na história das sociedades ocidentais modernas. A situação atual, caracterizada pelo aumento vertiginoso do desemprego na maioria dos países industrializados, pelo desmantelamento do modelo social de mercado alemão, pela progressiva mas constante redução dos direitos trabalhistas, pela concorrência entre países, que querem oferecer às empresas condições mais vantajosas a custa dos empregados, etc., e considerada por Honneth um mero desenvolvimento errado de um processo que, de outra forma, poderia ter levado a uma sociedade mais justa e não, como acham outros autores, como a consequência inevitável de certa lógica imperante nas últimas décadas de privatizações e desregulamentações (Pinzani, 2012, p. 213).

Em um movimento em direção à articulação entre teoria e empiria, Pinzani elenca as cinco condições apresentadas por Honneth que permitiriam um melhor exercício da liberdade social: existência de garantias jurídicas para a participação política dos indivíduos, presença de 
um espaço comunicativo comum, existência de um sistema diferenciado de mídia, a disponibilidade dos cidadãos a se engajarem nas discussões políticas, desenvolvimento de um sentimento de solidariedade cívica mantido por uma correspondente cultura política de solidariedade. Se estas já são condições a serem conquistadas em países desenvolvidos da Europa ocidental, o que dizer das condições de possibilidade em países como o Brasil ou outros países sem tradição de solidariedade cívica e/ou condições mínimas de igualdade. A abstração da análise teórica propicia compreensões complexas, não maniqueístas e multideterminadas. A tarefa de construir dimensões e mediações capazes de dialogar com a vida concreta é sempre uma missão igualmente complexa quando se almeja guardar a riqueza da sua teia de relações abstratas.

É preciso, no entanto, ressaltar que Honneth, na obra em questão, não se propõe a fazer uma reconstrução histórica ou descritiva, mas sim uma "reconstrução normativa" (Honneth, 2011, p. 23 e ss.). Ele afirma explicitamente que, com esse termo, ele pretende distanciar sua proposta de uma teoria meramente descritiva ou histórica, ou seja, não seria relevante para a sua teoria fazer uma história mundial do surgimento e desenvolvimento das sociedades modernas ou de instituições como o mercado financeiro, muito menos seria relevante para sua teoria se ele teria tratado exaustiva e adequadamente de todos os eventos históricos considerados importantes por essa ou aquela corrente da pesquisa. Na verdade, ele pretende, através dessa reconstrução, "deixar transparecer", de forma imanente, o substrato normativo das sociedades contemporâneas que têm a pretensão de serem democráticas. Em outras palavras, se determinada sociedade optar por concretizar a democracia, ela necessariamente terá de trabalhar com a "gramática normativa" descrita por Honneth em seu livro. Portanto, se a sociedade $\mathrm{X}$ ou $\mathrm{Y}$ não conseguiu concretizar ainda em suas instituições os valores por ele descritos, ou se o momento histó- 
rico $\mathrm{X}$ ou $\mathrm{Y}$ denota um retrocesso na concretização desses valores, isso, por si só, não é relevante para a teoria do autor. Relevante é, sim, o fato de que, se o observador ou o participante desta sociedade quiser criticar essa não concretização ou esse retrocesso do ponto de vista de um Estado Democrático de Direito, ele, necessariamente, utilizará a gramática normativa por ele descrita, porque ela está vinculada imanentemente com o "mundo da concretização da liberdade", que é o direito moderno, estrutural e institucionalmente ancorado nas democracias modernas.

Discussões como as que se travaram aqui contribuem a mostrar que, se a obra de Honneth foi capaz de recolocar esse debate no centro das discussões acadêmicas internacionais, é porque ela tem um potencial especulativo e teórico para se tornar um clássico da teoria social e de filosofia. Só este fato já justifica a elaboração de um dossiê a seu respeito, tal qual o presente número da Revista Sociologias. Espera-se que o debate promovido pelos textos do presente dossiê contribua decisivamente para uma recepção crítica da Teoria do Reconhecimento de Axel Honneth.

\section{Referências}

ANDERSON, Joel; HONNETH, Axel. Autonomia, Vulnerabilidade, Reconhecimento e Justiça. Cadernos de Filosofia Alemã, FFLCH-USP, São Paulo, n. 17, jan./jun. 2011, p.81-112.

CARDOSO DE OLIVEIRA, Luís Roberto. Racismo, direitos e cidadania. Estudos avançados, São Paulo, n. 18, 2004, p. 80-93.

CORRÊA, Andressa da Silva. Entre o homem de bem e comum: Um estudo sobre o substrato motivacional para as lutas por reconhecimento em associados de empreendimentos econômicos solidários. 2012. 150 f. Dissertação (Mestrado em Sociologia), PPG de Sociologia, IFCH, UFRGS, Porto Alegre.

HEGEL, G.W.F. (1830) [Enzyklopädie III]. Enzyklopädie der philosophischen Wissenschaften III. In: MICHEL, Karl Markus, MOLDENHAUER, Eva (Org.). Werke in 20 Bänden. Vol. 10. Frankfurt am Main: Suhrkamp, 1986. 
HEIDEGREN, Carl-Göran. Anthropology, Social Theory, and Politics: Axel Honneths's Theory of Recognition. Inquiry. Vol. 45, n. 4, 2002, p. 433-446.

HONNETH, Axel. Kritik der Macht. Reflexionsstufen einer kritischen Gesellschaftstheorie. Frankfurt am Main: Suhrkamp, 1986a.

HONNETH, Axel. Nachwort (1988). In: Kritik der Macht. Reflexionsstufen einer kritischen Gesellschaftstheorie. Frankfurt am Main: Suhrkamp, 1986b, p. 380406.

HONNETH, Axel. Kampf um Anerkennung. Zur moralischen Grammatik sozialer Konflikte. Frankfurt: Suhrkamp, 1992 [Tradução: HONNETH, Axel. Luta por reconhecimento; a gramática moral dos conflitos sociais. São Paulo: Ed. 34, 2003a].

HONNETH, Axel. Leiden an Unbestimmtheit. Eine Reaktualisierung der Hegelschen Rechtsphilosophie. Stuttgart: Reclam, 2001 [Tradução: HONNETH, Axel. Sofrimento de indeterminação, uma reatualização da filosofia do direito de Hegel. São Paulo: Esfera Pública, 2007].

HONNETH, Axel. Redistribution as Recognition: a response to Nancy Fraser. In: FRASER, Nancy, HONNETH, Axel. Redistribution or Recognition; a politicalphilosophical exchange. London/New York: Verso, 2003b.

HONNETH, Axel, Der Grund der Anerkennung. Eine Erwiderung auf kritische Rückfragen. In: HONNETH, Axel. Kampf um Anerkennung. Zur moralischen Grammatik sozialer Konflikte. Frankfurt am Main: Suhrkamp, 2003c.

HONNETH, Axel, Umverteilung als Anerkennung. Eine Erwiderung auf Nancy Fraser. In: Fraser, Nancy, HONNETH, Axel. Umverteilung oder Anerkennung? Eine politisch-philosophische Kontroverse. Frankfurt am Main: Suhrkamp, 2003d.

HONNETH, Axel, Unsichtbarkeit. Stationen einer Theorie der Intersubjektivität. Frankfurt am Main: Suhrkamp, 2003e.

HONNETH, Axel. Antworten auf die Beiträge der Kolloquiumsteilnehmer. In: Halbig, Christoph; Quante, Michael. Axel Honneth: Sozialphilosophie zwischen Kritik und Anerkennung. Münster: Lit Verlag, 2004.

HONNETH, Axel. Verdinglichung. Eine anerkennungstheoretische Studie. Frankfurt am Main: Suhrkamp, 2005.

HONNETH, Axel. La société du mépris; vers une nouvelle Théorie Critique. Paris: La Découverte, 2006.

HONNETH, Axel. Aneignung von Freiheit. Freuds Konzeption der individuellen Selbstbeziehung. In: HONNETH, Axel. Pathologien der Vernunft. Geschichte und Gegenwart der Kritischen Theorie. Frankfurt am Main 2007b, p. 157-179. 
HONNETH, Axel. Observações sobre a reificação. Civitas, Porto Alegre, v. 8, n. 1, jan.-abr. 2008, p. 68-79.

HONNETH, Axel. Von der Begierde zur Anerkennung. Hegels Begründung von Selbstbewusstsein (2008b). In: HONNETH, Axel. Das Ich im Wir. Studien zur Anerkennungstheorie. Frankfurt am Main: Suhrkamp, 2010, p. 15-32.

HONNETH, Axel. Das Recht der Freiheit. Grundri einer demokratischen Sittlichkeit. Frankfurt am Main: Suhrkamp, 2011.

HONNETH, Axel, JOAS, Hans. Soziales Handeln und menschliche Natur. Anthropologische Grundlagen der Sozialwissenschaft. Frankfurt/New York: Campus, 1980.

HÖSLE, Vittorio: Hegels System. Der Idealismus der Subjektivität und das Problem der Intersubjektivität. 2a. Ed. Rev. Aum. Hamburg: Meiner, 1998.

PINZANI, Alessandro. O valor da liberdade na sociedade contemporânea. Novos estudos CEBRAP, São Paulo, n. 94, nov. 2012, p. 207-215.

SAAVEDRA, Giovani. A teoria crítica de Axel Honneth. In: SOUZA, Jessé; MATTOS, Patrícia. Teoria crítica no século XXI. São Paulo: Annablume, 2007.

SOUZA, Jessé. A gramática moral da desigualdade brasileira. In: SOUZA, Jessé (Org.). A invisibilidade da desigualdade brasileira. Belo Horizonte: Editora UFMG, 2006. 